\title{
An Employee Engagement Instrument and Framework Building on Existing Research
}

\author{
Hester Nienaber \\ Nico Martins \\ University of South Africa (Unisa) \\ Email: nienah@unisa.ac.za and martin@unisa.ac.za
}

\section{Doi:10.5901/mjss.2014.v5n20p485}

\section{Abstract}

\begin{abstract}
Employee engagement is important as it contributes to an organisation's competitive advantage and improved performance. Despite heightened attention different conceptualisations, measures and explanations of 'engagement' exist. Research findings in connection with 'engagement' are not unanimous, leaving room for further investigation. Areas of concern include the conceptualisation of the concept and validity of widely used instruments measuring engagement, while cultural differences may influence understanding of items and subsequently impact validity of the measurement instrument. Thus, this study developed an employee engagement instrument and framework, building on existing literature, in particular, Macey and Schneider, measuring engagement concurrently at the organisational and individual levels. This research focusses on the first phase of the development of a new instrument, namely construct validity. Measuring employee engagement at both the individual and organisational levels simultaneously can assist organisations in leveraging their competitive advantage, and improve organisational performance. The researchers conducted an in-depth literature review, thus this research is qualitative, descriptive and conceptual in nature. The proposed engagement framework consists of seven dimensions, each comprising a number of items representing the individual and organisational levels. This framework provides conceptual clarification on employee engagement at the individual, team and organisational levels and, together with the instrument, a basis to leverage competitive advantage. The value of this original research stems from integrating employee engagement at the individual and organisational levels. Furthermore, a clearly defined, theoretical employee engagement measurement framework and instrument for the South African context were developed. Subsequent studies will be undertaken to validate this framework.
\end{abstract}

Keywords: competitive advantage; employee engagement; work engagement; measurement instrument; organisational performance

\section{Introduction}

Employee engagement, whether at the organisational or the individual level, has recently received heightened attention in the literature. This intensified attention stems from the role employee engagement plays in sustaining competitive advantage, which could lead to improved business results and successful organisational performance (Attridge, 2009; Barnes \& Collier, 2013; Fearon, McLaughlin \& Morris, 2013; Gruman \& Saks, 2011; Jeung, 2011; Klassen, Aldhafri, Mansfield, Purwanto, Siu, Wong \& Woods-McConney, 2012; Lewis, 2011; Lockwood, 2007; Mills, Culbertson \& Fullagar, 2012; Sustainable employee engagement, 2013; Van Rooy, Whitman, Hart \& Caleo, 2011). Engagement, which is a complex concept (Lockwood, 2007), has been described as "slippery" (Schaufeli \& Salanova, 2011) and different reasons are advanced for the elusiveness of the concept. On the one hand, it is argued that employee engagement and work engagement - which are two different concepts (Kahn, 1990; Saks, 2006) - are treated as the same by most researchers and practitioners (Schaufeli \& Salanova, 2011). According to Schaufeli and Salanova (2011), employee engagement is a broader concept than work engagement, which may include the employee's professional or occupational role and his or her relationship with the organisation, while work engagement refers to the (individual) employee's work. On the other hand, it is argued that the construct itself and its measurement are not well developed (Christian, Garza \& Slaughter, 2011; Frese, 2008; Hirschfeld \& Thomas, 2008; Jeung, 2011; Macey \& Schneider, 2008; Masson, Royal, Agnew \& Fine, 2008; Robertson \& Cooper, 2010; Schaufeli \& Salanova, 2011; Seppälä et al., 2009; Simpson, 2009; Van Rooy et al., 2011; Viljevac, Cooper-Thomas \& Saks, 2012). This is evidenced in the different definitions proposed in the literature (Christian et al., 2011; Endres \& Mancheno-Smoak, 2008; Gruman \& Saks, 2011; Juniper, 2012; Kahn, 1990; Lewis, 2011; Saks, 2006) as well as the interchangeable use of psychological states, traits and behaviours and their antecedents and outcomes (Macey \& Schneider, 2008) which result in different measures of the construct, and divergent outcomes of studies aiming at validating employee engagement instruments (Klassen et al., 2012; Viljevac et al., 2012). In addition, different theories such as the exchange theory (Saks, 2006) and motivation theories (Christian et al., 2011; 
Kahn, 1990; Meyer \& Gagné, 2008; Salanova, Agut \& Peiro, 2005) are also used to explain engagement. All of these different treatments of engagement result in different outcomes which are not coherent, underscoring the point made by Viljevac et al. (2012) that the use of different descriptions and measures results in findings which will be specific to each of these, thus limiting generalisability across studies, which will both slow theoretical progress and reduce the ability of science to contribute to practice.

It stands to reason that the different treatments of engagement, whether at the organisational or individual levels, hamper the shaping of competitive advantage to the detriment of organisational performance. The notion of competitive advantage, first used by Alderson (1964), in essence means that an organisation attracts customers on the basis of superior value offered in comparison to competitors. Hence, competitive advantage is described as valuable, rare, inimitable and non-substitutable and associated with the "resource-based view of the firm" (Barney, 1991). As such, competitive advantage arises from something that an organisation's competition cannot do, or from doing something better than the organisation's competition (Alderson, 1964; Barney, 1991; David, 2013). In order to be persistent, competitive advantage should be embedded in the organisation.

More recent research (Nienaber, Cant \& Strydom, 2002; Ordóňez de Pablo \& Lytras, 2008) has shown that competitive advantage consists of three dimensions, namely: (i) the arena where the organisation chooses to compete; (ii) customer value (customer capital); and (iii) access to the required resources, including employees (talent or human capital), processes and systems (structural capital), and assets to provide customer value in the chosen arena. Employees are the most important of these dimensions, specifically in terms of their knowledge, skills, experience, attitudes and behaviours, which are open to change owing to changes in the workplace (Endres \& Mancheno-Smoak, 2008; Fawcett, Rhoads \& Burnah, 2004; Frese, 2008; Holbeche, 2009; Laszlo \& Laszlo, 2002; Masson et al., 2008; Ordóňez de Pablo \& Lytras, 2008; Owen, 1813; Pfeffer, 2010; Piersol, 2007; Van Rooy et al., 2011).

This short account of competitive advantage shows its centrality to the organisation's success from a strategic management perspective. Hence, an understanding of the connection between an individual's job and organisational strategy is a requirement for success (Cheese, Thomas \& Craig, 2008; Fawcett et al., 2004; Lockwood, 2007) as it drives employee engagement (Lewis \& Heckman, 2006; Lockwood, 2007), which facilitates organisational performance (Crook, Todd, Combs, Woehr \& Ketchen, 2011; Harter, Schmidt \& Hayes, 2002; Heskett, Jones, Loveman, Sasser \& Schlesinger, 1994; Lockwood, 2007; Piersol, 2007).

The ambiguity associated with the concept of engagement jeopardises achieving a competitive advantage and thus organisational performance as expressed in business results. Given the importance of engagement, the researchers set out to develop an employee engagement measuring instrument, reflecting engagement at both the organisational and individual levels, for the South African context by drawing on the framework of Macey and Schneider (2008) - as adapted - and considering the comments on the framework.

\section{Purpose of the Study}

The purpose of the study on which this article is based was to develop an engagement measurement framework and instrument by building on the framework proposed by Macey and Schneider (2008), tailoring it for the South African context and drawing on the existing theory of employee engagement.

\section{Current theoretical Perspectives}

According to Van Rooy et al. (2011), research on engagement is in a stage of relative infancy and more research is needed to understand its antecedents, process mechanisms and outcomes. Frese (2008) mentions that a number of authors have contributed to this concept under different labels, which calls for clarification; while Saks (2008) suggests that the current theories and measurement instruments need further development, refinement and integration. This view is supported by Fearon, et al. (2013), Klassen et al., 2012; Robertson and Cooper (2010), Seppäla et al. (2009) and Viljavec et al. (2012). Authors seem unanimous in the view that engagement is a multidimensional, multilevel construct (Cheese et al., 2008; Christian et al., 2011; Frese, 2008; Gruman \& Saks, 2011; Harter et al., 2002; Kahn, 1990; Lockwood, 2007; Macey \& Schneider, 2008; Masson et al., 2008; May, Gilson \& Harter, 2004; Mills et al., 2012; Parker \& Griffin, 2011; Robertson \& Cooper, 2010; Saks, 2006, 2008; Schaufeli, Salanova, González-Romá \& Bakker, 2002, 2006; Seppäla et al., 2009; Van Rooy et al., 2011). It is, therefore, a complex construct. It further appears that authors disagree on the exact dimensions and/or terminology to identify these dimensions (Dalal, Brummel, Wee \& Thomas, 2008; Frese, 2008; Griffin, Parker \& Neal, 2008; Hirschfeld \& Thomas, 2008; Juniper, 2012; Macey \& Schneider, 2008; Robertson \& Cooper, 2010; Saks, 2008; Schaufeli \& Salanova, 2011) and whether positive (psychological) states and behaviour are 
consequences of engagement or an unsatisfactory situation, which a person with certain traits might want to improve (Frese, 2008; Masson et al., 2008; Parker \& Griffin, 2011). Authors also seem unanimous that tenets of engagement (partially) overlap with other constructs which are employee focused (Employee Outlook, 2012; Endres \& ManchenoSmoak, 2008; Frese, 2008; Juniper, 2012; Kahn, 1990; Masson et al., 2008; Newman \& Harrison, 2008; Parker \& Griffin, 2011; Robertson \& Cooper, 2010), thus threatening discriminant validity (Saks, 2008; Harter \& Schmidt, 2008; Newman \& Harrison, 2008). However, the study conducted by Christian et al. (2011) indicated discriminant validity in the case of the Macey and Schneider (2008) framework.

Frese (2008) does not differentiate between engagement, personal initiative, proactivity, taking charge and voice, because these are very similar concepts. However, he is of the opinion that it is necessary to develop active performance concepts (proactive personality and personal initiative behaviour), of which engagement is one, and the function of positive affectivity (for engagement) given the changing nature of the world of work.

Masson et al. (2008) point out that the engagement concepts used by consultants encompass, in some combination, affective commitment (pride in the organisation; willingness to recommend the organisation as an employer), continuance commitment (intention to remain with the organisation) and discretionary effort (feeling inspired by the organisation; being willing to go above and beyond formal role requirements), linking engagement to the organisational level; whereas the academic literature generally refers to engagement at the work level (though Saks 2006 covers both).

Despite these differences a number of instruments measuring engagement are available (Attridge, 2009; Bakker, Schaufeli, Leiter \& Taris, 2008; Barnes \& Collier, 2013; Christian et al., 2011; Jeung, 2011; Masson et al., 2008; Simpson, 2009; Van Rooy et al., 2011), whether provided by academics (May et al., 2004; Schaufeli et al., 2002) or practitioners (such as Gallup Blessing White, Hewitt, Sirota, Valtera, Watson Wyatt Worldwide \& Towers Watson mentioned in Attridge 2009). Some of the instruments provided by academics focus on (psychological) state engagement (as proposed by Kahn 1990 and disclosed by authors such as Rothman \& Rothman, 2010) like the Utrecht Work Engagement Scale (UWES); while others (such as Gallup and those proposed by Saks 2006 and Harter et al., 2002) are used by practitioners and focus on the organisational level. According to Attridge (2009), most of these instruments measure engagement at the individual level. Nevertheless, Van Rooy et al. (2011) point out that these measures fall short of identifying actionable insights and solutions. This point is implicitly supported by Masson et al. (2008). Hence, they suggest that engagement measurement instruments should account for a variety of factors, phrased in a meaningful way that can be understood and acted upon (Van Rooy et al., 2011). This is congruent with the view of Aguinis and Edwards (2014) that research should be rigorous (valid) as well as relevant for practice of management. Moreover, instruments should be reliable and valid (Masson et al., 2008) to be useful. Rothmann and Rothmann (2010) point out that the reliability of the UWES was less than optimal in their research and more research is needed to develop an instrument that is reliable but also measures the physical, emotional and cognitive components of engagement. Viljavec et al. (2012) used the UWES and the May et al. (2004) scales - the two most often used engagement scales measuring engagement on the individual (work) level in the academic literature - and found that although the UWES demonstrated higher validity than the May et al. (2004) measure, neither measure should be considered an adequate measure of work engagement, which is consistent with information provided in previous paragraphs. This finding is not surprising, given that Aguines and Edwards (2014) point out that studies using multiple indicators typically fail to report reliability estimates. These points further underscore that the construct of engagement is not properly conceptualised, hence it cannot be appropriately operationalised. Authors in the field have therefore called for further research.

\section{Research Design}

\subsection{Research approach}

The researchers in the current study relied on an in-depth literature study, aiming at understanding the phenomenon of employee engagement. This research was descriptive and conceptual in nature. A realist interpretive style was used because the researchers believe that employee engagement is real and exists separate from people's thoughts about it. Furthermore, employee engagement is accessible to those who investigate the phenomenon. However, knowledge about employee engagement is not necessarily an accurate reflection of reality as it is possible for people to know more or less objectively (Fisher, 2010). This study thus focused on "Step 1: Item generation" of the scale development process as portrayed by Hinkin (1998) in Figure 1, which is in line with the guidance provided by Edwards (2001; 2011) and Edwards and Bagozzi (2000). 


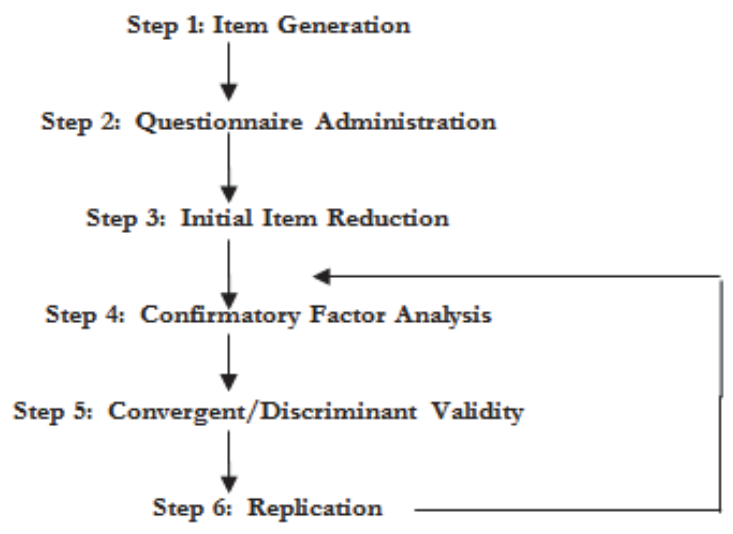

Figure 1: Scale development process (Hinkin,1998)

\subsection{Research method}

The research strategy comprised an in-depth literature review, which is described as a synthesis review (Kirkevold, 1997; Richards \& Morse, 2013). During this type of review, isolated information is integrated into a more comprehensive and internally consistent whole. It thus facilitates the integration of separate studies with different focuses and uses a variety of methodologies to provide a comprehensive account of the phenomenon being reviewed. This type of review is a powerful knowledge-development tool as it enables knowledge to be accumulated that goes beyond merely evaluating the strength and weaknesses of existing knowledge to create a whole new and more informative understanding of the phenomenon studied (Kirkevold, 1997; Richards \& Morse, 2013).

\subsection{Targeted body of literature}

Initially, literature pertaining to employee engagement (at both the organisational and the individual levels) was targeted. Because the research was conceptual in nature, the first interest was in conceptual articles relating to employee engagement. Thereafter, literature pertaining to the measurement of constructs encapsulated by employee engagement was targeted.

\subsection{Data gathering}

The researchers set the study within business research, with an emphasis on organisational psychology. Hence, business and organisational psychology databases were searched for articles (in English) pertaining to employee engagement at both the individual and organisational levels, whether conceptual or empirical. The databases searched were Proquest, EbscoHost, Emerald and SABINET, the leading databases in the field of business (including organisational psychology). In addition, sources from the Chartered Institute of Personnel Development (CIPD) were consulted. The search yielded a total of 921 possible articles, of which 53 met the inclusion criteria for the construct "engagement" at the individual, unit and/or organisational levels and/or its measurement and/or validation of engagement measuring instruments. A further 170 textbooks and 76 dissertations/theses were yielded.

Macey and Schneider (2008:6) maintain that leadership has a direct effect on trust and an indirect effect, through trust, on behavioural engagement. An illustration of the (adapted) engagement framework proposed by Macy and Schneider (2008) is shown in Figure 2 below. 


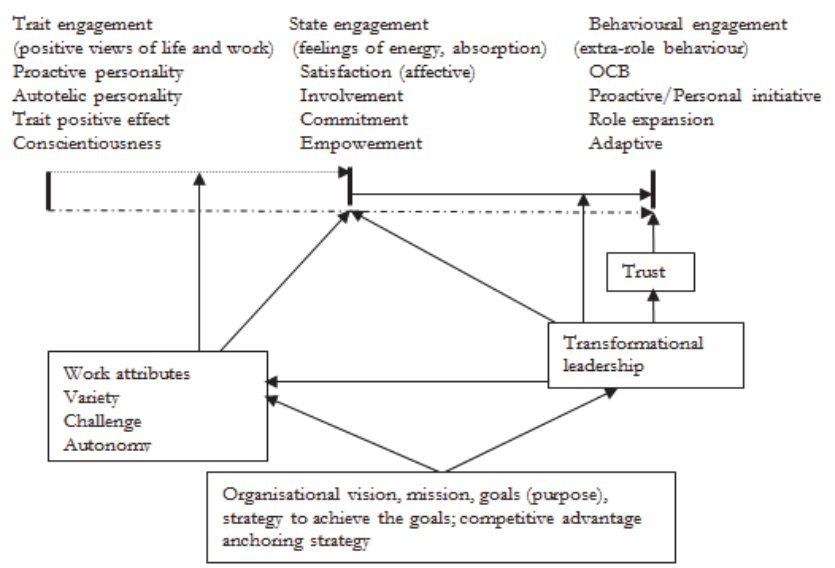

(Adapted from Macey and Schneider, 2008:6)

\section{Figure 2: Engagement framework}

Figure 2 warrants a few observations. The framework consists of seven components representing the individual, team/department and organisational levels. The individual level involves the components (psychological) trait, state and behavioural engagement; the team/departmental level comprises the components work, leadership and trust; and the organisational level has the components organisational vision, mission, goals, purpose, strategy and competitive advantage to achieve organisational goals. It should be noted that each component of the framework of engagement consists of a number of constructs which share similar item content with measures of other constructs. Nevertheless, Figure 2 is useful from a theoretical perspective, which has practical utility, as it illustrates the antecedents (trait engagement, work characteristics, leadership, trust and organisational vision, mission, goals, strategy and competitive advantage) as well as consequences (behavioural engagement) of engagement that influence organisational performance. Antecedents influence engagement, which in turn have an impact on consequences and thus organisational performance.

The phrasing of the measurement items (see Aguinis \& Edwards, 2014; Klassen et al., 2012; Mason et al., 2008; van Rooy et al., 2011), suggested by available measurement items, may pose a challenge to typically South African respondents due to differences in language and idiomatic expressions. Moreover, measurement instruments developed among populations of workers in Westernised countries are difficult to apply to populations in low-income countries as they fail to take into account certain dimensions of the construct that may be specific to a country, continent or culture (such as the value of work, social organisation and religion), thereby compromising their validity (Faye, Fournier, Diop, Philibert, Morestin \& Dumont, 2013; Klassen et al., 2012). The available instruments measuring some or other dimension of engagement all consist of numerous items, illuminated in Table 1, which will thus be impractical to use in the South African context. Hence, the researchers reverted to designing, and will subsequently validate, the measuring instrument which, if not carefully constructed, may also be cumbersome and produce the same type of outcome as previously constructed instruments. Nevertheless, this designed measuring instrument would provide for dimensions of engagement and engagement facets. These facets are considered to be interwoven with the construct "engagement". Because these facets are not empirically distinct, they cannot be separated. Consequently, there is no possibility "of differential impacts on engagement" that can be studied (Saunders \& Thornhill, 2004).

Macey and Schneider (2008) clarified each of the elements of their proposed engagement framework. In so doing, they arrived at several propositions relating to the relationship between engagement and the elements constituting the framework, which relate to both the individual (job/work) and the organisation, indicating that the individual (job/work) and organisation exist in relation to each other. This idea is also consistent with our conception of competitive advantage as set out in the previous section. These propositions are portrayed in Table 2.

\subsection{Organisational level}

The researchers in this study added the organisational level because the organisational level of measurement includes aspects of engagement that cannot be captured by (merely) aggregating individual/unit measures (Pugh \& Dietz, 2008). 
Employees who are engaged at the organisational level know what their organisation does, can articulate its competitive advantage accurately and care passionately about its customers (Dyer, 2009). Thus, the vision, mission, goals, values and principles which set the direction of the organisation; the strategy to achieve the goals; and competitive advantage, the foundation of strategy, are included. These aspects are generally measured by items such as "communicate to employees what the organisation's goals are" and how to achieve them.

The exposition of engagement provided by Macey and Schneider (2008) shows that engagement should be considered at both the individual and the organisational levels, as the organisational level influences engagement at the unit and individual levels.

\section{Results}

The engagement instrument was constructed with due regard to existing instruments measuring the dimensions comprising the construct. Table 1 gives examples of research done from 1990 to 2013 focusing on engagement at both the organisational and individual levels. The summary in Table 1 highlights the different purposes of measuring engagement, the dimensions used, the method/analysis and the key findings. It is clear from this summary that the purposes of measurement vary greatly, although most studies focus on some aspect(s) of engagement, and that different constructs are applied when measuring engagement. Different dimensions are measured and the key findings differ due to the methods applied to analyse the data as well as the different contexts in which the assessments were done. In a number of instances structural equation modelling was used to confirm the theoretical models developed. An interesting observation is that in most instances, existing questionnaires or measuring instruments were combined to measure employee engagement.

Table 1: Examples of selected studies focusing on 'engagement' 1990-2013

\begin{tabular}{|c|c|c|c|c|}
\hline Author(s) & $\begin{array}{l}\text { Purpose of the study/ } \\
\text { Measuring Instrument }\end{array}$ & Dimensions & Method/Analysis & Key Findings* \\
\hline \multicolumn{5}{|c|}{ Conceptual papers } \\
\hline \begin{tabular}{|l|} 
Kahn, \\
1990
\end{tabular} & $\begin{array}{l}\text { To conceptualise } \\
\text { personal engagement by } \\
\text { exploring the working } \\
\text { conditions in which } \\
\text { people personally engage } \\
\text { and disengage }\end{array}$ & $\begin{array}{l}\text { - Meaningfulness } \\
\text { - task characteristics } \\
\text { - role characteristics } \\
\text { - work interactions } \\
\text { - Psychological safety } \\
\text { - interpersonal relationships } \\
\text { - group and intergroup dynamics } \\
\text { - management style and process } \\
\text { - organisational norms } \\
\text { - Psychological vailability } \\
\text { - physical energy } \\
\text { - emotional energy } \\
\text { - insecurity } \\
\text { - outside life }\end{array}$ & $\begin{array}{l}\text { In-depth } \\
\text { interviews; } \\
\text { grounded theory }\end{array}$ & $\begin{array}{l}\text { Three psychological conditions } \\
\text { (meaningfulness, safety and availability) are } \\
\text { identified. These concepts help to explain the } \\
\text { variance between people bringing to and } \\
\text { leaving out aspects of themselves in their } \\
\text { work role performances. }\end{array}$ \\
\hline \begin{tabular}{|l} 
Macey \& \\
Schneider, \\
2008
\end{tabular} & $\begin{array}{l}\text { Developed a theoretical } \\
\text { framework }\end{array}$ & $\begin{array}{l}\text { - Trait engagement (positive views of life and } \\
\text { work), proactive personality, autotelic } \\
\text { personality trait, positive effect, } \\
\text { conscientiousness } \\
\text { - State engagement (feelings of energy, } \\
\text { absorption), satisfaction (affective), } \\
\text { involvement, commitment, empowerment } \\
\text { - Behavioural engagement (extra-role behaviour), } \\
\text { organisational citizenship behaviour (OCB), } \\
\text { proactive/personal initiative, role expansion, } \\
\text { adaptive } \\
\text { - Trust } \\
\text { - Transformational leadership } \\
\text { - Work attributes (variety, challenge, autonomy) }\end{array}$ & $\begin{array}{l}\text { Developed a } \\
\text { theoretical } \\
\text { framework }\end{array}$ & $\begin{array}{l}\text { They offer propositions about the effects of } \\
\text { job attributes and leadership as main effects } \\
\text { on state and behavioural engagement and as } \\
\text { moderators of the relationships among the } \\
\text { three facets of engagement. } \\
\text { They conclude with thoughts about the } \\
\text { measurement of the three facets of } \\
\text { engagement and potential antecedents, } \\
\text { especially measurement via employee } \\
\text { surveys. }\end{array}$ \\
\hline \multicolumn{5}{|c|}{ Developing and validating engagement measurement instruments } \\
\hline $\begin{array}{l}\text { Schaufeli } \\
\text { et al., } \\
2002, \\
2006\end{array}$ & $\begin{array}{l}\text { UWES identified three } \\
\text { sub-dimensions of } \\
\text { engagement: vigour, } \\
\text { dedication, absorption; } \\
\text { characteristics of }\end{array}$ & $\begin{array}{l}17 \text { item scale } \\
\text { - Vigour (6), } \\
\text { - Dedication (5), } \\
\text { - Absorption (6) } \\
\text { Nine item scale }\end{array}$ & $\begin{array}{l}\text { Confirmatory } \\
\text { factor analysis; } \\
\text { Multiple- } \\
\text { group } \\
\text { confirmatory }\end{array}$ & $\begin{array}{l}\text { Confirmed UWES (17 and nine item scales) } \\
\text { validity and reliability as a representative } \\
\text { instrument of } \\
\text { engagement in multinational cultural contexts } \\
\text { and samples }\end{array}$ \\
\hline
\end{tabular}




\begin{tabular}{|c|c|c|c|c|}
\hline Author(s) & $\begin{array}{l}\text { Purpose of the study/ } \\
\text { Measuring Instrument }\end{array}$ & Dimensions & Method/Analysis & Key Findings* \\
\hline & $\begin{array}{l}\text { engagement are more } \\
\text { persistent and pervasive } \\
\text { affective-cognitive } \\
\text { psychological state' }\end{array}$ & $\begin{array}{l}\text { - Vigour (3), } \\
\text { - Dedication (3), } \\
\text { - Absorption (3) }\end{array}$ & factor analysis & \\
\hline $\begin{array}{l}\text { May et al., } \\
2004\end{array}$ & $\begin{array}{l}\text { To test Kahn's (1990) } \\
\text { conceptualisation of } \\
\text { engagement by } \\
\text { examining the } \\
\text { determinants and } \\
\text { mediating effects of three } \\
\text { psychological conditions } \\
\text { (meaningfulness, safety } \\
\text { and availability) on } \\
\text { engagement at work }\end{array}$ & $\begin{array}{l}\text { - Psychological engagement (13) } \\
\text { - Psychological meaningfulness (6) } \\
\text { - Psychological safety (3) } \\
\text { - Psychological availability (5) } \\
\text { - Job enrichment (15) } \\
\text { - Work role fit (4) } \\
\text { - Rewarding co-worker relations (10) } \\
\text { - Supportive supervision relations (10) } \\
\text { - Co-worker norm adherence (3) } \\
\text { - Resources (8) } \\
\text { - Self-consciousness (3) } \\
\text { - Outside activities (11) }\end{array}$ & $\begin{array}{l}\text { Questionnaire; } \\
\text { path analysis }\end{array}$ & $\begin{array}{l}\text { Among the three psychological conditions, } \\
\text { meaningfulness displays the strongest } \\
\text { relation to engagement. The relationships of } \\
\text { job enrichment and work role fit to } \\
\text { engagement are partially mediated by } \\
\text { psychological safety. } \\
\text { Model developed: Path-analytic framework of } \\
\text { engagement. }\end{array}$ \\
\hline \begin{tabular}{|l} 
Barnes \& \\
Collier, \\
2013
\end{tabular} & $\begin{array}{l}\text { To contribute to the } \\
\text { developing literature on } \\
\text { work engagement by } \\
\text { studying antecedents, } \\
\text { outcomes and } \\
\text { measurement, } \\
\text { specifically in a services } \\
\text { environment }\end{array}$ & $\begin{array}{l}\text { Use existing measures to construct a } 42 \text { item } \\
\text { instrument: } \\
\text { - Work engagement } \\
\text { - Service climate (5) } \\
\text { - Job satisfaction (4) } \\
\text { - Affective commitment } \\
\text { - Adaptability (5) } \\
\text { - Career commitment (6) }\end{array}$ & $\begin{array}{l}\text { Questionnaire; } \\
\text { Structural } \\
\text { equation } \\
\text { modelling }\end{array}$ & $\begin{array}{l}\text { Empirical evidence that service climate, job } \\
\text { satisfaction and affective commitment } \\
\text { influence work engagement; } \\
\text { Work engagement is conceptualised as a } \\
\text { multidimensional higher order construct that } \\
\text { exhibits a superior fit compared to a simple } \\
\text { first order conceptualization }\end{array}$ \\
\hline \multicolumn{5}{|c|}{ Validating engagement measurement instruments } \\
\hline $\begin{array}{l}\text { Storm \& } \\
\text { Rothman, } \\
2003\end{array}$ & $\begin{array}{l}\text { Self-report questionnaire } \\
\text { to } \\
\text { assess work engagement } \\
\text { (UWES) }\end{array}$ & $\begin{array}{l}\text { Work engagement scale - UWES (24 items } \\
\text { consisting of vigour, dedication and absorption) }\end{array}$ & $\begin{array}{l}\text { Structural } \\
\text { equation } \\
\text { modelling }\end{array}$ & $\begin{array}{l}\text { Structural equation modelling confirms a } \\
\text { three-factor model of work engagement } \\
\text { consisting of vigour, dedication and } \\
\text { absorption. }\end{array}$ \\
\hline \begin{tabular}{|l|} 
Balducci, \\
Fraccaroli \\
$\&$ \\
Schaufeli, \\
2010 \\
\end{tabular} & $\begin{array}{l}\text { Validating the nine-factor } \\
\text { UWES (Italian) }\end{array}$ & $\begin{array}{l}\text { - Vigour } \\
\text { - Dedication } \\
\text { - Absorption }\end{array}$ & $\begin{array}{l}\text { Multiple-group } \\
\text { confirmatory } \\
\text { factor analyses }\end{array}$ & $\begin{array}{l}\text { The Italian version of the UWES-9 behaves } \\
\text { consistently with its original Dutch version }\end{array}$ \\
\hline $\begin{array}{l}\text { Christian } \\
\text { et al., } \\
2011\end{array}$ & $\begin{array}{l}\text { To test the model of } \\
\text { Macey and Schneider } \\
\text { (2008) }\end{array}$ & $\begin{array}{l}\text { - Autonomy } \\
\text { - Task variety } \\
\text { - Task significance } \\
\text { - Feedback } \\
\text { - Transformational leadership } \\
\text { - Conscientiousness } \\
\text { - Positive affect } \\
\text { - Work engagement } \\
\text { - Task performance } \\
\text { - Contextual performance }\end{array}$ & \begin{tabular}{|l|} 
Meta-analytic \\
path modelling \\
(The data \\
suggest that \\
Macey and \\
Schneider's \\
[2008] assertion \\
appears to have \\
merit: rather than \\
being merely a \\
blend of "old \\
wines", \\
engagement also \\
has \\
characteristics of \\
"new wines".) \\
\end{tabular} & $\begin{array}{l}\text { The path model suggests that task variety } \\
\text { and task significance appear to be related to } \\
\text { engagement. } \\
\text { They found tentative evidence that leadership } \\
\text { is related to work engagement and work } \\
\text { engagement is related to job performance. }\end{array}$ \\
\hline $\begin{array}{l}\text { Mills et al., } \\
2012\end{array}$ & $\begin{array}{l}\text { Validating UWES 17- and } \\
\text { nine item scale }\end{array}$ & $\begin{array}{l}\text { 1. Vigour } \\
\text { - Dedication } \\
\text { - Absorption }\end{array}$ & $\begin{array}{l}\text { Exploratory factor } \\
\text { analysis; } \\
\text { confirmatory } \\
\text { factor analysis } \\
\end{array}$ & $\begin{array}{l}\text { Supports a multifactorial conceptualisation of } \\
\text { the construct }\end{array}$ \\
\hline \begin{tabular}{|l} 
Viljavec et \\
al., 2012
\end{tabular} & $\begin{array}{l}\text { Investigated validity of } \\
\text { UWES and May et al. } \\
2004 \text { scale measuring } \\
\text { engagement }\end{array}$ & $\begin{array}{l}\text { UWES } \\
\text { (vigour, dedication and absorption) } \\
\text { May et al. } 2004 \\
\text { (cognitive, emotional and physical) }\end{array}$ & $\begin{array}{l}\text { Questionnaire; } \\
\text { Confirmatory } \\
\text { factor analysis } \\
\text { and structural } \\
\text { equation } \\
\text { modelling }\end{array}$ & $\begin{array}{l}\text { Some evidence for convergent, discriminant } \\
\text { and predictive validity was found for both } \\
\text { scales, although neither showed discriminant } \\
\text { validity with regard to job satisfaction. Overall, } \\
\text { the three factors of the UWES performed } \\
\text { slightly better across analyses than the three } \\
\text { factors from the May, Gilson and Harter } \\
\text { (2004) measure. }\end{array}$ \\
\hline \multicolumn{5}{|c|}{ Studies testing engagement and related concepts } \\
\hline \begin{tabular}{|l} 
Laschinger \\
\& Leiter,
\end{tabular} & $\begin{array}{l}\text { To test a theoretical } \\
\text { model of professional }\end{array}$ & $\begin{array}{l}\text { - Strong leadership (4) } \\
\text { - RN/MD collaboration (9) }\end{array}$ & $\begin{array}{l}\text { Questionnaire; } \\
\text { structural }\end{array}$ & $\begin{array}{l}\text { Burnout partially mediates the relationship } \\
\text { between work-life factors and adverse }\end{array}$ \\
\hline
\end{tabular}




\begin{tabular}{|c|c|c|c|c|}
\hline Author(s) & $\begin{array}{l}\text { Purpose of the study/ } \\
\text { Measuring Instrument }\end{array}$ & Dimensions & Method/Analysis & Key Findings ${ }^{*}$ \\
\hline 2006 & $\begin{array}{l}\text { nurses' work } \\
\text { environments linking } \\
\text { conditions for } \\
\text { professional nursing } \\
\text { practice to } \\
\text { burnout/engagement and } \\
\text { nurses' reports of } \\
\text { adverse patient events }\end{array}$ & $\begin{array}{l}\text { - Policy involvement (3) } \\
\text { - Staffing adequacy (4) } \\
\text { - Nursing model of care (8) } \\
\text { - Emotional exhaustion (9) } \\
\text { - Depersonalisation (5) } \\
\text { - Personal accomplishment (8) } \\
\text { - Adverse events (multi-analysis question) }\end{array}$ & $\begin{array}{l}\text { equation } \\
\text { modelling }\end{array}$ & $\begin{array}{l}\text { events. A work environment with higher } \\
\text { support for professional practice results in } \\
\text { higher engagement and ultimately safer } \\
\text { patient care. }\end{array}$ \\
\hline $\begin{array}{l}\text { Salanova } \\
\text { et al., } \\
2005\end{array}$ & $\begin{array}{l}\text { To test the mediating role } \\
\text { of service climate } \\
\text { between the antecedents } \\
\text { (organisational resources } \\
\text { and work engagement) } \\
\text { and employee } \\
\text { performance and } \\
\text { customer loyalty }\end{array}$ & $\begin{array}{l}\text { Organisational resources (training, autonomy, } \\
\text { technology) (11) } \\
\text { Service climate (4) } \\
\text { Work engagement - UWES (vigour, dedication, } \\
\text { absorption) (17) } \\
\text { Employee performance (6) } \\
\text { Customer loyalty (3) }\end{array}$ & $\begin{array}{l}\text { Structural } \\
\text { equation } \\
\text { modelling }\end{array}$ & $\begin{array}{l}\text { A full mediation model in which organisational } \\
\text { resources and work engagement predict } \\
\text { service climate, which in turn predicts } \\
\text { employee performance and customer loyalty, } \\
\text { is supported. }\end{array}$ \\
\hline $\begin{array}{l}\text { Hakanen } \\
\text { et al., } \\
2006\end{array}$ & $\begin{array}{l}\text { To test a model with two } \\
\text { parallel processes of } \\
\text { work-related well-being } \\
\text { among teachers: an } \\
\text { energetic process and a } \\
\text { motivational process }\end{array}$ & $\begin{array}{l}\text { - Work engagement - UWES (vigour, dedication, } \\
\text { absorption) (17) } \\
\text { - Burnout and ill health (10) } \\
\text { - Job demands and resources - eight dimensions } \\
\text { (20) } \\
\text { - Organisational commitment (2) }\end{array}$ & $\begin{array}{l}\text { Questionnaire; } \\
\text { structural } \\
\text { equation } \\
\text { modelling }\end{array}$ & $\begin{array}{l}\text { Burnout mediates the effect of high job } \\
\text { demands on ill health, work engagement } \\
\text { mediates the effects of job resources on } \\
\text { organisational commitment and burnout } \\
\text { mediates the effects of a lack of resources on } \\
\text { low work engagement. }\end{array}$ \\
\hline \begin{tabular}{|l|} 
Llorens et \\
al., 2006 \\
\end{tabular} & $\begin{array}{l}\text { To simultaneously test } \\
\text { the job-demands- } \\
\text { resource model in two } \\
\text { countries by using } \\
\text { different occupational } \\
\text { samples }\end{array}$ & $\begin{array}{l}\text { - Work engagement - UWES (vigour, dedication, } \\
\text { absorption) (17) } \\
\text { - Quantitative overload (3) } \\
\text { - Emotional overload (3) } \\
\text { - Job control (5) } \\
\text { - Social support (5) } \\
\text { - Performance feedback (3) } \\
\text { - Organisational commitment (4) } \\
\text { - Burnout (9) } \\
\text { Based on Spanish questionnaire }\end{array}$ & $\begin{array}{l}\text { Questionnaire; } \\
\text { structural } \\
\text { equation } \\
\text { modelling }\end{array}$ & $\begin{array}{l}\text { The hypothesis is partially supported: burnout } \\
\text { partially mediates the effect of job demands } \\
\text { on organisational commitment and work } \\
\text { engagement partially mediates the effect of } \\
\text { job resources on organisational commitment. }\end{array}$ \\
\hline $\begin{array}{l}\text { Hallberg et } \\
\text { al., } 2007\end{array}$ & $\begin{array}{l}\text { To examine the effects of } \\
\text { type A behaviour patterns } \\
\text { on burnout and work } \\
\text { engagement }\end{array}$ & $\begin{array}{l}\text { - Autonomy } \\
\text { - Workload } \\
\text { - Achievement striving } \\
\text { - Irritability/Impatience } \\
\text { - Work engagement - UWES (9) } \\
\text { - Emotional exhaustion - burnout } \\
\text { - Cynicism - burnout }\end{array}$ & $\begin{array}{l}\text { Questionnaire, } \\
\text { hierarchical } \\
\text { regression } \\
\text { analysis }\end{array}$ & $\begin{array}{l}\text { Type A behaviour and work engagement } \\
\text { share only } 13 \% \text { of common variance; no } \\
\text { significant interactions between type A and } \\
\text { workload. }\end{array}$ \\
\hline
\end{tabular}

Note: * may be influenced by type/kind of sample (e.g. probability vs non-probability like convenience); ( ) No of items if available

Adapted from Simpson (2009)

The researchers in this study started with a pool of 91 items that had to be measured, as reflected by the existing theory and after investigating other research as indicated in Table 1. The process that was followed to select the items was as follows:

- List all possible items, as per theoretical research, per proposition.

- Categorise items according to dimensions and sub-dimensions.

- Select only items which adhere to the criteria of item construction, such as:

- those that reflected the purpose of the questionnaire and the constructs of interest

- those that were seemingly redundant - to ensure that the content, which is common to the items of each dimension, will summate across items

- in the item pool, a larger number than intended was used in the final questionnaire (to reduce possible poor internal consistency) that were not exceptionally lengthy

- those that had appropriate reading difficulty levels to ensure that participants from all language groups and education levels would understand them

- those that were clear and concise with no problematic wording

- those that had appropriate grammatical structures and word choices

(DeVellis, 2003)

After discussions with various experts in the field of Industrial and Organisational Psychology and the field of 
Human Resources, items were (where needed) rephrased or added (or overlapping items were deleted), leaving a pool of 82 items.

The instrument consisted of two sections, namely a section collecting biographical/demographic information (qualifications, experience and tenure) and a section soliciting responses, using a five-point Likert scale, on statements about engagement at the individual level (50 statements), team/departmental level (12 statements) and organisational level (10 statements).

Table 2 gives an overview of the propositions, dimensions, dimension definitions, sub-dimensions, examples of typical items and the level of engagement measured. As shown in Table 2, it appears as if some items may be used to measure more than one proposition. However, this will be clarified by factor analysis and item analysis when validating the instrument.

Table 2: Proposed propositions, dimensions, items and levels of engagement

Proposition
Proposition 1: Satisfaction
This dimension measures aspects such as
the energy at work, if the work is inspiring
and enjoyable.
Proposition 2: Organisational
commitment
Consisting of 3 sub-dimensions this
construct measures energy to support the
organisation, feeling pride to be a member
of the organisation and personal
identification with the organisation.

Proposition 3: Job involvement Focuses on task engagement and job commitment.

Proposition 4: Feelings of empowerment The dimension focuses on the necessary knowledge and skills needed as well as the work environment.

Proposition 5: Job and work settings The focus of this dimension is feelings of persistence, vigour, energy and dedication.

Proposition 6: Feelings regarding involvement

The concepts of self-esteem, self-efficiency and self-identity are measured.

Proposition 7: Engagement behaviours Innovative behaviours and initiative are measured.

\section{Proposition 8: Engagement behaviour} actions

This dimension focuses on behaviours related to work engagement Proposition 9: Role expansion behaviours

The focus of this dimension is on aspects such as job related opportunities and challenges

Proposition 10: Behavioural engagement Dimension: Behaviour engagement The focus in this dimension is on teamwork.
Proposition 11: Engagement as a disposition proactive personality and autotelic personality are measured.
The concepts of conscientiousness,

\section{Dimension/Sub-dimension}

Dimension: Satisfaction

Sub-dimension: Feeling of energy

Sub-dimension: Enthusiasm

Dimension: Organisational commitment

Sub-dimension: Energy to support the organisation

Sub-dimension: Feel pride as an organisational member

Sub-dimension: Personal identification with the organisation

Dimension: Job involvement

Sub-dimension: Task engagement

Sub-dimension: Job commitment

Dimension: Feelings of

Dimension: Job and work setting (feelings of persistence, vigour, energy, dedication, etc) Dimension: Feelings regarding

involvement

Dimension: Engagement behaviours Dims Dimension: Engagement behaviour actions

Dimension: Role expansion behaviours empowerment

\section{Typical Items}

- At my work I feel bursting with energy.

- I feel enthusiastic about my work.

- I feel committed to the organisation.

- Our brand is well known in the market.

- I am excited by our vision and mission.

- My job role is clearly defined.

- I enjoy my work. my job.

- I have the necessary skills to do my job.

- My job is meaningful to me.

- I feel my work provides for work-life balance.

- My role makes good use of my skills and abilities.

- In our organisation individual employees accept accountability for their performance.

- The organisation has a stimulating environment.

- Initiative is encouraged in the organisation.

- I get carried away when I am working.

- When I get up in the morning, I feel like going to work.

- At my job, I always persevere even when things do not go well.

- I feel our service to our customers usually exceeds their expectations.
- I have the necessary knowledge to do

Levels of engagement Individual level

Individual level

Individual level

Individual level

Organisational level

Organisational level

Individual level

Individual level

In my team we will finalise a task even if Organisational/team level we experience difficulties.

- In my team we adapt to changes.

Dimension: Engagement as a disposition Sub-dimension: Conscientiousness Sub-Dimension: The proactive personality Sub-dimension: Autotelic personality • I am often so consumed in my job I lose track of time.
Organisational/team and individual levels
- My team conducts their work in an orderly manner.

- Mistakes are viewed as a learning opportunity in our organisation. 


\section{Proposition \\ Proposition 12: Engagement outputs \\ Productivity, customer satisfaction,}

revenues and leadership are included in this dimension.

Proposition 13: Feelings of trust Dimension: Feelings of trust

Trust between managers, subordinates and colleagues are measured.

Proposition 14: Personal and environment fit issues on engagement Team goal achievement is measured, as well as organisational conditions, organisational strategy and performance measurement.

\begin{tabular}{|c|c|}
\hline Dimension/Sub-dimension & Typical Items \\
\hline Dimension: Engagement outputs & $\begin{array}{l}\text { - We identify the opportunities for our } \\
\text { customers. } \\
\text { - My immediate manager inspires people } \\
\text { in my team. }\end{array}$ \\
\hline Dimension: Feelings of trust & $\begin{array}{l}\text { - I trust my immediate manager. } \\
\text { - I trust my colleagues. }\end{array}$ \\
\hline \multicolumn{2}{|l|}{$\begin{array}{l}\text { Dimension: Personal and } \\
\text { environment fit issues on } \\
\text { engagement }\end{array}$} \\
\hline Sub-dimension: Goal achievement & $\begin{array}{l}\text { - My team continuously strives to improve } \\
\text { performance in line with our business } \\
\text { objectives. }\end{array}$ \\
\hline $\begin{array}{l}\text { Sub-dimension: Organisational } \\
\text { conditions }\end{array}$ & $\begin{array}{l}\text { In my organisation managers accept } \\
\text { responsibility for their business units. }\end{array}$ \\
\hline
\end{tabular}

Levels of engagement

Organisational level

Individual level

Team/organisational leve

\section{Conclusion and Implications}

The main research objective of this study was to develop a measurement instrument to measure employee engagement concurrently at both the individual level and organisational level, tailored for the South African context. Most engagement measurement instruments are designed to measure engagement at either the individual level (Kahn, 1990; Rothman \& Rothman, 2010; Schaufeli \& Salanova, 2011) or the organisational level (Q12 of Gallup). Furthermore, there is no consensus in the literature on the dimensions comprising engagement, nor on the labels identifying these dimensions (Dalal et al., 2008; Frese, 2008; Griffin et al., 2008; Hirschfeld \& Thomas, 2008; Macey \& Schneider, 2008; Masson et al., 2008; Schaufeli \& Salanova, 2011; Simpson, 2009; Van Rooy et al., 2011). The engagement measurement instrument reflects the different levels of engagement as well as a variety of dimensions as indicated in the (adapted) Macey and Schneider (2008) framework.

The researchers concluded that engagement is indeed a complex construct. It is recommended that this instrument be validated to ensure its reliability and factorial validity for the South African context and to determine whether it covers, in its current form, acceptable psychometric properties that can be used to measure the core components of employee engagement. It is envisaged that the proposed measuring instrument will be revised and adapted more than once before it will cover most of the core components of employee engagement.

A possible limitation is that only sources in English were consulted.

It is suggested that future research be conducted to test the measuring instrument for reliability and validity in various South African environments and that the theoretical model should also be tested by means of structural equation modelling to determine the relationships between dimensions. These represent steps 2 to 6 of the scale development process of Hinkin (1998) as portrayed in Figure1.

\section{References}

Aguinis, H. \& Edwards, J.R. (2014). Methodological wishes for the next decade and how to make wishes come true. Journal of Management Studies, 51, 143-174.

Alderson, W. (1964). A normative theory of marketing systems, in Theory in marketing edited by Cox, Alderson and Shapiro. Homewood, III: Richard D. Irwin, Inc.

Attridge, M. (2009). Measuring and managing employee work engagement: A review of the research and business literature. Journal of Workplace Behavioral Health, 24, 4, 383-398.

Bakker, A.B., Schaufeli, W., Leiter, M.P. \& Taris, T.W. (2008). "Work engagement: An emerging concept in occupational health psychology". Work and Stress, 22, 3, 187-200.

Balducci, C. Fraccaroli, L. \& Schaufeli, W.B. (2010). Psychometric Properties of the Italian Version of the Utrecht Work Engagement Scale (UWES-9) A Cross-Cultural Analysis. European Journal of Psychological Assessment, 26, 2, 143-149. DOI: 10.1027/1015$5759 / a 000020$

Barnes, D.C. \& Collier, J.E. (2013). Investigating work engagement in the service environment. Journal of Services Marketing, 27, 6, 485-499. DOI 10.1108/JSM-01-2012-0021.

Barney, J.B. (1991). Firm resources and sustained competitive advantage. Journal of Management, 17, 1, $99-120$.

Cheese, P., Thomas, R.J. \& Craig, E. (2008). The talent powered organisation: Strategies for globalisation, talent management and high performance. London: Kogan Press Limited.

Christian, M.S., Garza, A.S. \& Slaughter, J.E. (2011). Work engagement: A quantitative review and test of its relations with task and 
contextual performance. Personnel Psychology, 64, 89-136.

Crook, T.R., Todd, S.Y., Combs, J.G., Woehr, D.J. \& Ketchen, D.J. (2011). Does human capital matter? A meta-analysis of the relationship between human capital and firm performance. Journal of Applied Psychology, 96, 443-456.

Dalal, R.S., Brummel, B.J., Wee, S. \& Thomas, L.L. (2008). Defining employee engagement for productive research and practice. Industrial and Organizational Psychology, 1, 52-55.

David, F.R. (2013). Strategic management: Concepts and cases. 13 ${ }^{\text {th }}$ edition. Upper Saddle River, NJ: Pearson International.

DeVellis, R.F. (2003). Scale development: Theory and application. $2^{\text {nd }}$ edition. Thousand Oaks, CA: Sage Publications.

Dyer, K. (2009). Taking employee engagement to new heights. SCM, Vol. 13, No, 4, pp. 1.

Edwards, J.R. (2001). Multidimensional constructs in organizational behaviour research: An integrative framework. Organizational Research Methods, 4, 2, 144-192.

Edwards, J.R. (2011). The fallacy of formative measurements. Organizational Research Methods, 14, 2, 370-388.

Edwards, J.R. \& Bagozzi, R.P. (2000). On the nature and direction of relationships between constructs and measures. Psychological Methods, 5, 2, 55-174.

Employee Outlook, (2012). Charted Institute of Personnel Development, Thousand Oaks, CA.

Endres, G.M. \& Mancheno-Smoak, L. (2008). The human resource craze: Human performance and employee engagement. Organization Development Journal, 26, 1, 69-78.

Fearon, C., McLaughlin, H. \& Morris, L. (2013). Conceptualising work engagement: An individual, collective and organisational efficacy perspective. European Journal of Training and Development, 37, 3, 244-256.

Fawcett, S.E., Rhoads, G.K. \& Burnah, P. (2004). People as the bridge to competitiveness: Benchmarking the 'ABCs' of an empowered workforce. Benchmarking, 11, 4, 346-360.

Faye, A., Fournier, P., Diop, I., Philibert, A., Morestin, F. \& Dumont, A. (2013). Developing a tool to measure satisfaction among health professionals in sub-Saharan Africa. Human Resources for Health, 11, 30-41.

Fisher, C. (ed). (2010). Researching and writing a dissertation: An essential guide for business students. $3^{\text {rd }}$ edition. Essex: Pearson.

Frese, M. (2008). The world is out: We need an active performance concept for modern workplaces. Industrial and Organizational Psychology, 1, 67-69.

Griffin, M.A., Parker, S. K. \& Neal, A. (2008). Is behavioural engagement a distinct and useful construct? Industrial and Organizational Psychology, 1, 48-51.

Gruman, J.A. \& Saks, A.M. (2011). Performance management and employee engagement. Human Resource Management Review, 21, 123-136.

Hakanen, J.J., Bakker, A.B. \& Schaufeli, W.B. (2006). Burnout and work engagement among teachers. Journal of School Psychology, $43, .495-513$

Hallberg, U., Schaufeli, W.B. \& Johansson, G. (2007). Type A behaviour and work situation: Associations with burnout and work engagement. Scandinavian Journal of Psychology, 48, 135-142.

Harter, J.K. \& Schmidt, F.L. (2008). Conceptual versus empirical distinctions among constructs: Implications for discriminant validity. Industrial and Organisational Psychology, 1, 36-39.

Harter, J.K., Schmidt, F.L. \& Hayes, T.L. (2002). Business-level-unit relationship between employee satisfaction, employee engagement, and business outcomes: A meta-analysis. Journal of Applied Psychology, 87, 2, 268-279.

Heskett, J.L., Jones, T.O., Loveman, G.W., Sasser, W.E. Jnr, \& Schlesinger, L.A. (1994). Putting the service-profit chain to work. Harvard Business Review, March-April, 164-170.

Hinkin, T.R. (1998). A brief tutorial on the development of measures for use in survey questionnaires. Organisational Research Methods, $1,104-121$.

Hirschfeld, R.R. \& Thomas, C.H. (2008). Representations of trait engagement: Integration, additions, and mechanisms. Industrial and Organizational Psychology, 1, 63-66.

Holbeche, L. (2009). Aligning human resources and business strategy. $2^{\text {nd }}$ edition. Oxford: Butterworth- Heinemann.

Jeung, C.W. (2011). The Concept of Employee Engagement: A Comprehensive Review from a Positive Organizational Behavior Perspective. Performance Improvement Quarterly, 24, 2, 49-69. DOI: 10.1002/piq.

Juniper, B. (2012). Engagement versus wellbeing. Occupational Health, 64, 4, 26.

Kahn, W.A. (1990). Psychological conditions of personal engagement and disengagement at work. Academy of Management Journal, 33, 4, 692-724.

Klassen, R.M., Aldhafri, S., Mansfield, C.F., Purwanto, E., Siu, A.F.Y., Wong, M.W. \& Woods-McConney, A. (2012). Teachers' Engagement at Work: An International Validation Study. The Journal of Experimental Education, 80, 4, 317-337.

Kirkevold, M. (1997). Integrative nursing research - An important strategy to further the development of nursing science and nursing practice. Journal of Advanced Nursing, 25, 977-984.

Laschinger, H.K.S. \& Leiter, M.P. (2006). The impact of nursing work environments on patient safety outcomes: The mediating role of burnout/engagement. Journal of Nursing Administration, 36, 5, 259-267.

Laszlo, K.C. \& Laszlo, A. (2002). Evolving knowledge for development: The role of knowledge management in a changing world. Journal of Knowledge Management, 6, 4, 400-412.

Lewis, R. (2011). Management competencies for enhancing employee engagement. Research Insights, Charted Institute of Personnel Development, London.

Lewis, R.E. \& Heckman, R.J. (2006). Talent management: A critical review. Human Resource Management Review, 16, $139-154$. 
Llorens, S., Bakker, A.B., Schaufeli, W.B. \& Salanova, M. (2006). Testing the robustness of the job demands-resources model. International Journal of Stress Management, 13, 378-391.

Lockwood, N. (2007). Leveraging employee engagement for competitive advantage: HR's strategic role. Society for Human Resource Management Research, Quarterly, 3, 1, 1-11.

Macey, W.H. \& Schneider, B. (2008). The meaning of engagement. Industrial and Organizational Psychology, 1, 3-30.

Masson, R.C., Royal, M.A., Agnew, T.G. \& Fine, S. (2008). Leveraging employee engagement: The practical implications. Industrial and Organizational Psychology, 1, 56-59.

May, D.R., Gilson, R.L. \& Harter, L.M. (2004). The psychological conditions of meaningfulness, safety and availability and the engagement of the human spirit at work. Journal of Occupational and Organizational Psychology, 77, 1, 11-37.

Meyer, J.P. \& Gagné, M. (2008). Employee engagement from a self-determination theory perspective. Industrial and Organizational Psychology, 1, 60-62

Mills, M.J., Culbertson, S.S. \& Fullagar, C.J. (2012). Conceptualizing and Measuring Engagement: An Analysis of the Utrecht Work Engagement Scale. Journal of Happiness Studies, 13, 519-545. DOI 10.1007/s10902-011-9277-3.

Newman, D.A. \& Harrison, D.A. (2008). Been there, bottled that: Are state and behavioral work engagement new and useful construct 'wines'? Industrial and Organizational Psychology, 1, 31-35.

Nienaber, H., Cant, M.C. \& Strydom, J.W. (2002). An exploratory investigation into the application of market strategies by selected JSElisted companies in the food sector in the period 1996-1999. Southern African Business Review, July, 6, 1, 24-30.

Ordóňez de Pablo, P. \& Lytras, M.D. (2008). Competencies and human resource management: Implications for organizational competitive advantage. Journal of Knowledge Management, 12, 6, 48-55.

Owen, R. (1813). An address to the superintendants of manufactories, in Classics in management edited by HF Merrill 1970. [S.I.]: American Management Association.

Parker, S.K. \& Griffin, M.A. (2011). Understanding active psychological states: Embedding engagement in a wider nomological net and closer attention to performance. European Journal of Work and Psychology, 20, 1, 60-70.

Pfeffer, J. (2010). Building sustainable organizations: The human factor. Academy of Management Perspective, February, 34-45.

Piersol, B. (2007). Employee engagement and power to the edge. Performance Improvement, 46, 4, 30-33.

Pugh, S.D. \& Dietz, J. (2008). Employee engagement at the organisational level of analysis. Industrial and Organizational Psychology, 1 , 44-47.

Richards, L. \& Morse, J. (2013). Qualitative methods. $3^{\text {rd }}$ edition. London: Sage Publications.

Robertson, I.T. \& Cooper, C.L. (2010). Full engagement: The integration of employee engagement and psychological well-being. Leadership and Organizational Development, 31, 4, 324-336. Available at http://dx.doi.org/101108/01437731011043348 (accessed 22 March 2012).

Rothmann, S. \& Rothmann, S. (2010). Factors associated with employee engagement in South Africa. South African Journal of Industrial Psychology, 36, 2, Art. \#925, 12 pages, DOI: 10.4102/sajip.v36i2.925.

Saks, A.M. (2006). Antecedents and consequences of employee engagement. Journal of Managerial Psychology, 21, 7, 600-619.

Saks, A.M. (2008). The meaning and bleeding of employee engagement: How muddy is the water? Industrial and Organizational Psychology, 1, 40-43.

Salanova, M., Agut, S. \& Peiro, J.M. (2005). Linking organizational resources and work engagement to employee performance and customer loyalty: The mediation of service climate. Journal of Applied Psychology, 90, 6, 1217-1227.

Saunders, M.N.K. \& Thornhill, A. (2004). Trust and mistrust in organizations: An exploration using an organizational justice framework. European Journal of Work and Organisational Psychology, 13, 4, 493-515.

Schaufeli, W.B., Bakker, A.B. \& Salanova, M. (2006). The Measurement of Work Engagement With a

Short Questionnaire A Cross-National Study. Educational and Psychological Measurement, 66, 4, 701-716.

Schaufeli, W.B. \& Salanova, M. (2011). Work engagement: On how to better catch a slippery concept. European Journal of Work and Organization Psychology, 20, 1, 39-46.

Schaufeli, W.B., Salanova, M., González-Romá, V. \& Bakker, A. B. (2002). The measurement of engagement and burnout and: A confirmative analytic approach. Journal of Happiness Studies, 3, 71-92.

Seppälä, P., Mauno, S., Feldt, T., Hakanen, J., Kinnunen, U., Tolvanen, A., \& Schaufeli, W. (2009). The Construct Validity of the Utrecht Work Engagement Scale: Multisample and Longitudinal Evidence. Journal of Happiness Studies, 10, 459-481. DOI 10.1007/s10902-008-9100-y

Simpson, M. (2009). Engagement at work: A review of the literature. International Journal of Nursing Studies, 46, 1012-1024.

Storm, K. \& Rothman, S. (2003). A psychometric analysis of the Utrecht work engagement scale on the South African Police Force. South African Journal of Industrial Psychology, 29, 4, 62-70.

Sustainable employee engagement. Training and Development, February 2013, 67, 20.

Van Rooy, D.L., Whitman, D.S., Hart, D. \& Caleo, S. (2011). Measuring employee engagement during a financial downturn: Business imperative or nuisance? Journal of Business Psychology, 26, 147-152.

Viljevac, A., Cooper-Thomas, H.D. \& Saks, A. (2012). An investigation into the validity of two measures of work engagement. The International Journal of Human Resource Management, 23, 17, 3692-3709. 